\title{
Maalle oppimaan - tietoa, taitoja, elämyksiä, osallistumista!
}

Helmi Risku-Norja ${ }^{1}$, Anja Yli-Viikari ${ }^{1}$, Marja-Liisa Vieraankivi ${ }^{2}$, Anneli Nuoranne ${ }^{3}$, Elli Korpela $^{1}$, Pia Smeds ${ }^{1}$

${ }^{1}$ MTT Taloustutkimus, 31600 Jokioinen,

${ }^{2}$ MTT Biotekniikka ja elintarvikkeet ,31600 Jokioinen

${ }^{2}$ MTT Palveluyksikkö ,31600 Jokioinen

etunimi.sukunimi@mtt.fi

\section{Tiivistelmä}

Nykyajan palveluyhteiskunta on etäännyttänyt kansalaisensa monista elämän perusasioista. Etenkin kaupunkilaislasten ja -nuorten siteet luontoon ja maatalouteen ovat löyhtyneet, mutta ilmiö tulee vastaan yhä useammin myös maaseutukunnissa. Harvalla lapsella tai nuorella on tänä päivänä kokemuksia maaseudun elämästä. Vaikka merkittävä osa päivittäisistä kulutusvalinnoistamme liittyy ruokaan, tiedot ruoan tuotannosta ovat lisääntyvässä määrin puutteelliset. Mittava haaste on osoittaa, minkälainen yhteys maataloudella on ruokaan, kulttuuriin, maisemaan ja ympäristöön ja mikä on maatalouden yhteiskunnallinen ja kansantaloudellinen merkitys. Jotta pystymme vaikuttamaan ruoan saatavuuteen eli ruokaturvaan, tuotteiden laatuun eli ruokaturvallisuuteen ja tuotannosta aiheutuvaan ympäristökuormitukseen, on ruoantuotanto säilytettävä omissa käsissä. Tämä edellyttää, että kasvava sukupolvi oppii arvostamaan kotimaista ruokaa ja tietää, miten se on tuotettu.

Maaseutulähtöinen kestävän kehityksen kasvatus tarjoaa mahdollisuuden lähestyä näitä kysymyksiä perusopetuksen opetussuunnitelman pohjalta. Maatilat soveltuvat oivallisesti koulun ulkopuoliseen opetukseen, sillä kulttuurin ja luonnon vuorovaikutus näkyy viljelymaisemassa ja ympäröivässä luonnossa. Omakohtainen kosketus luontoon ja maatilan elämään ja toimintaan on luonteva keino lujittaa siteitä maaseutuun ja osoittaa ihmisen riippuvuus luonnosta ja omasta elinympäristöstään.

Koulujen ja maatilojen väliseen yhteistyöhön on luotu kaksi erilaista toimintamallia. Maalle oppimaan -leirikoulut toimivat maatiloilla. Niissä kestävän kehityksen kasvatusta toteutetaan toimintaa varten erityisesti suunniteltujen opetuskokonaisuuksien pohjalta, jotka tukevat kansallisen perusopetuksen opetussuunnitelman tavoitteita. Koulujen ja niitten läheisyydessä sijaitsevien maatilojen väliseen kanssakäymiseen on puolestaan kehitetty jatkuvaan yhteistyöhön perustuvaa toimintaa. Siinä opettaja yhdessä maatilayrittäjän kanssa suunnittelee maatilavierailujen sisällön, joka räätälöidään yksilöllisesti koulun tarpeiden ja maatilan tarjoamien puitteiden pohjalta. Lisäksi maatalouden esittelypuisto Elonkierto Jokioisilla on avoin yleisölle ja tarjoaa tietoa, toimintaa ja elämyksiä kaikenikäisille.

Maaseutulähtöinen kestävän kehityksen kasvatus on kokonaisvaltaista ja tilannesidonnaista, ja siinä yhdistyvät tieto, tekeminen, tunteet, aistit ja arvot. Se lisää koulun ja yhteiskunnan keskinäistä vuorovaikutusta. Yhteistyö opetustoimen kanssa lisää maatiloilla tehtävän työn arvostusta, ja se voi olla myös lisätulonlähde maatiloille. 


\section{Taustaa}

Vaikka ruoka ja syöminen ovat osa päivittäistä arkea, ruoan tuotanto ja sen alkuperä eivät sitä ole. Elintarvikkeiden maailmanlaajuiseksi kehittynyt kauppa ja valmisruokien kasvava kulutus ovat hämärtäneet lasten ja nuorten käsitystä ruoan reitistä pellolta pöytään. Samalla käsitys ihmisen ja luonnon tasapainoisesta vuorovaikutuksesta on katoamassa. Kaupunkilaislasten ja nuorten siteet maaseutuun ja maatalouteen ovat löyhtyneet, mutta ilmiö tulee vastaan yhä useammin myös maaseutukunnissa.

Maatalouden osuus Suomen BKT:sta on vain prosentin luokkaa (Niemi \& Ahlstedt 2006). Nyky-yhteiskunnassa, jossa toimialojen merkitystä arvioidaan voittopuolisesti taloudellisilla mittareilla, ei maatalouden arvostus ole kovin korkealla. Kuitenkin tämän tästä toistuvat maailmanlaajuiset ruokakriisit, ympäristöongelmat ruoan viejämaissa ja eri puolilla maailmaa esiintyvät nälänhädät ovat osoituksena globaalin ruoantuotannon haavoittuvuudesta ja riskeistä. Sekä ruokaturvan eli ruoan saatavuuden että ruokaturvallisuuden eli ruoan laadun kannalta kotimaiseen ruokaan liittyy vahvoja kestävyystekijöitä. Jotta pystymme jatkossakin vaikuttamaan ruoan saatavuuteen, tuotteiden terveellisyyteen ja tuotannosta aiheutuvaan ympäristökuormitukseen, tulisi ruoantuotannosta mahdollisimman suuri osuus pystyä ylläpitämään Suomessa. Tämä edellyttää, että kasvava sukupolvi oppii arvostamaan kotimaista ruokaa ja tietää, missä ja miten se on tuotettu. Mittava haaste on osoittaa nykyisille ja tuleville päättäjille ja kuluttajille, minkälainen yhteys maataloudella on ruokaan, kulttuuriin, maisemaan ja ympäristöön ja mikä on maatalouden yhteiskunnallinen merkitys.

Kestävä kehitys on maailmanlaajuinen jatkuva ja ohjattu yhteiskunnallinen muutos, jonka päämääränä on turvata nykyisille ja tuleville sukupolville hyvät elämisen edellytykset. Pyrkimyksenä on, että ympäristö, ihminen ja talous otetaan tasavertaisesti huomioon päätöksenteossa ja toiminnassa. Kestävän kehityksen ulottuvuudet ovat ekologinen, taloudellinen, kulttuurinen ja sosiaalinen. Näiden perusulottuvuuksien lisäksi kestävässä kehityksessä painottuvat myös esteettinen ja eettinen näkökulma (Cantell \& Koskinen 2004, kuva 1). Kestävässä kehityksessä ei siis ole kysymys yksinomaan ympäristöstä ja luonnon kantokyvystä, se on myös verkottumista ja yhdessä oppimista.

\section{Ekologinen $=$ fyysinen ympäristö}

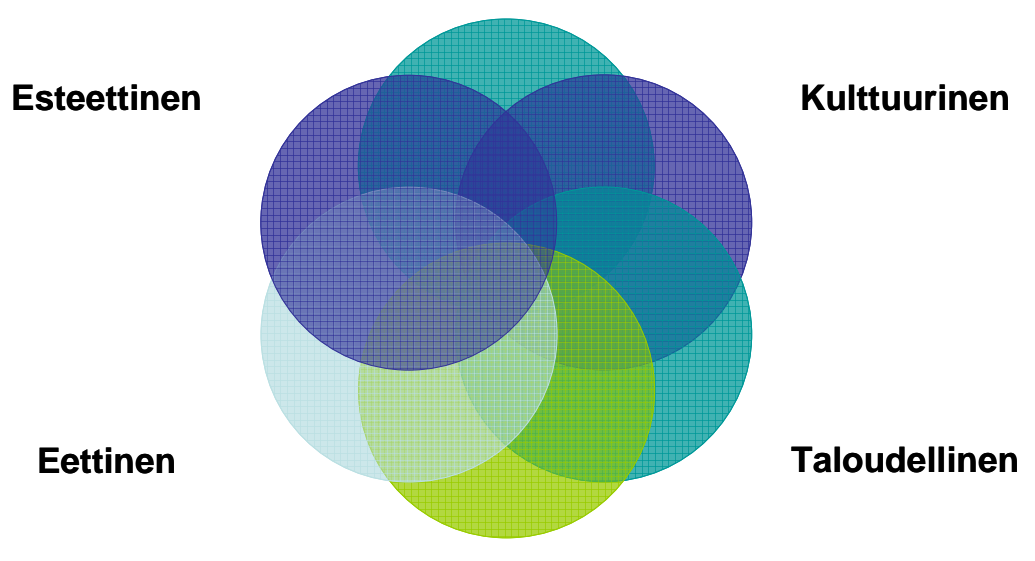

Sosiaalinen

Kuva 1. Kestävän kehityksen ulottuvuudet (Cantell \& Koskinen 2004). 
Maaseutulähtöisen kestävän kehityksen kasvatuksen tavoitteet ovat samat kuin kestävän kehityksen kasvatuksessa yleisestikin, mutta toiminnan painopiste on maaseutuympäristössä. Se on maaseututietoisuuteen kasvattamista, ruoan luonnonvarataustan, ruoan turvallisuuden ja kansainväliseen ruokahuoltoon liittyvän tiedon lisäämistä. Se lisää sekä maatalouden ja muiden luonnonvara-alojen tunnettavuutta ja kilpailukykyä että maaseutuyrittäjyyden arvostusta yhteiskunnassa (Siltala \& Kaivola 2003, Häkkinen 2005).

Maaseudun viljelymaisema ja sitä ympäröivä luonto ovat oleellinen osa luonnon monimuotoisuutta ja suomalaista identiteettiä. Maaseudun merkitys avautuu parhaiten aidossa ympäristössä. Omakohtainen kosketus maatilan elämään on luonteva keino lujittaa siteitä maaseutuun, lisätä ymmärrystä kulttuurin luontoperustasta ja osoittaa ihmisen riippuvuus luonnosta ja omasta elinympäristöstään. Oppivelvollisuuskoulu tavoittaa koko ikäluokan, joten yhteistyö koulujen kanssa on avainasemassa. Tavoitteena on edistää kestävää kehitystä kiinnittämällä huomio erityisesti lapsiin ja nuoriin. Pyrkimyksenä on lisätä heidän tietouttaan kulttuurin ja luonnon keskinäisestä vuorovaikutuksesta, vahvistaa siteitä koulun ja sen lähiympäristön välillä, luoda uusia tapoja kestävän kehityksen kasvatukseen sekä tuottaa opetusaineistoa.

\section{Maatilat oppimisympäristönä}

Maatilaa voidaan hyödyntää oppimisympäristönä eri tavoin, eikä tilojen käyttö opetuksessa olekaan harvinaista (Risku-Norja 2006). Toteutustavat vaihtelevat maatilavierailuista luokkaretkiin, kuuntelusta ja havainnoinnista aktiiviseen tilan töihin osallistumiseen ja maatilaleirikoulusta oman puutarhapalstan hoitoon lähimaatilalla.

Opetuksen kannalta on keskeistä, että oppiminen on kokonaisvaltaista ja tilannesidonnaista eli kontekstuaalista. Kokonaisvaltaisuudella tarkoitetaan, että oppimisessa yhdistyvät tieto, tekeminen, tunteet, aistit ja arvot ja että asioita tarkastellaan monesta eri näkökulmasta (Wahlström 1997, Chawla 1999, Saloranta 2005, Åhlberg 2005). Kontekstuaalinen oppiminen puolestaan edellyttää, että oppilas on kiinnostunut tarkasteltavasta asiasta, ymmärtää sen yhteydet aikaisempaan tietämykseensä ja pystyy soveltamaan oppimaansa arkisiin toimiinsa (Cantell 2004).

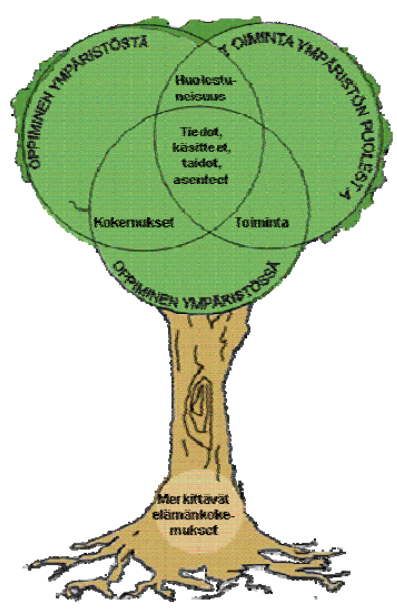

a)

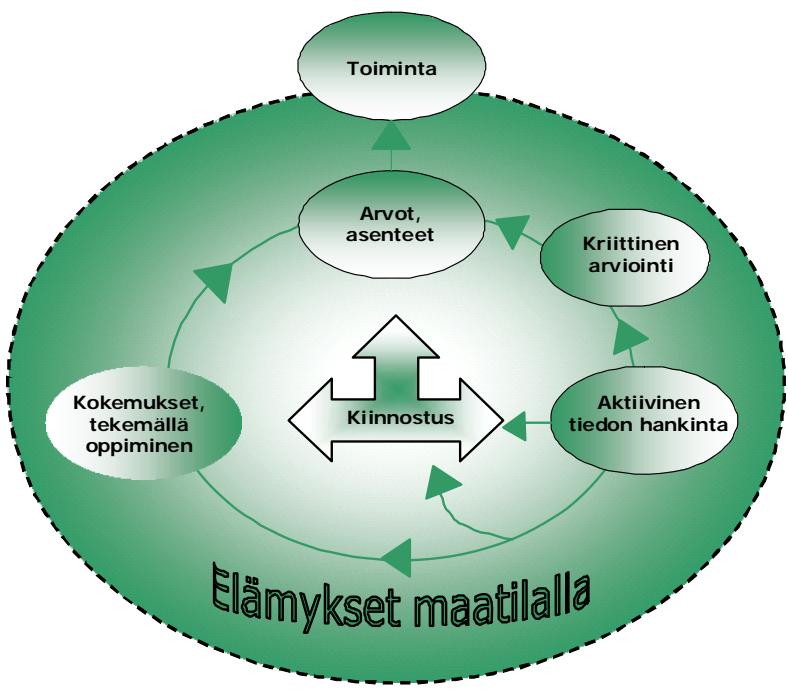

b)

Kuva 2. a) Palmerin puu ympäristökasvatuksen mallina (Palmer 1998). b) Kokonaisvaltainen, tilannesidonnainen oppiminen koulun ulkopuolisessa opetuksessa maatilalla. 
Ympäristöoppimista kuvataan usein puumallilla, jossa yhdistyvät oppiminen ympäristöstä, oppiminen ympäristössä ja oppiminen ympäristön hyväksi (Kuva 1a). Mallin mukaan omakohtaiset kokemukset muodostavat oppimisen perustan, puun rungon, johon tiedot, taidot ja asenteet kiinnittyvät (Palmer 1998). Mallia voidaan hyvin soveltaa myös maaseutulähtöisessä kestävän kehityksen kasvatuksessa. Tällöin ympäristö käsittää paitsi maatilan ja sitä ympäröivän luonnon myös ihmisen toiminnan ja sen vaikutukset sekä paikallistasolla että yhteiskunnan kannalta - jopa maailmanlaajuisia kysymyksiä myöten. Omakohtaiset elämykset maatilalla muodostavat tarttumapinnan uusille tiedoille ja taidoille, joita saadaan tekemällä, havainnoimalla ja käyttäen hyväksi kaikkia aisteja Tämä herättää kiinnostuksen, joka on kaiken oppimisen edellytys. Alkaa aktiivinen tiedonhankinta ja tiedon prosessointi, sillä uutta tietoa täytyy sovittaa aiempaan tietämykseen ja arvioida suhteessa siihen. Kiinnostus, tieto ja kriittinen arviointi muokkaavat arvoja ja asenteita. Vasta kun ne ovat kohdallaan, tieto kanavoituu käytännön toimintana ja arkisina tekoina, kuten kotimaisen ruoan suosimisena (Kuva 1b).

\section{Maaseutulähtöistä kestävän kehityksen kasvatusta monella tavalla}

\section{Elonkierto}

Elonkierto on MTT:n perustama maatalousaiheinen esittelypuisto, joka sijaitsee Loimijokilaaksossa Jokioisissa, keskellä maatalouden muovaamaa lounaishämäläistä kulttuurimaisemaa. Puiston pinta-ala on 20 ha ja sen alueella on mahdollisuus tutustua suomalaisen maatalouden historiaan, nykyisyyteen ja tulevaisuuden näkymiin. Puistossa tutustutaan myös maataloustutkimukseen ja sen uusimpiin tuloksiin. Suosituimpia kohteita on maatiaiseläinten ohella "Suomalainen ruokapöytä, jossa yhden suomalaisen vuoden aikana kuluttamat elintarvikkeet on muutettu raaka-aineiden tuottamiseen tarvittavaksi peltopinta-alaksi ja näytetään peltomaisemana.

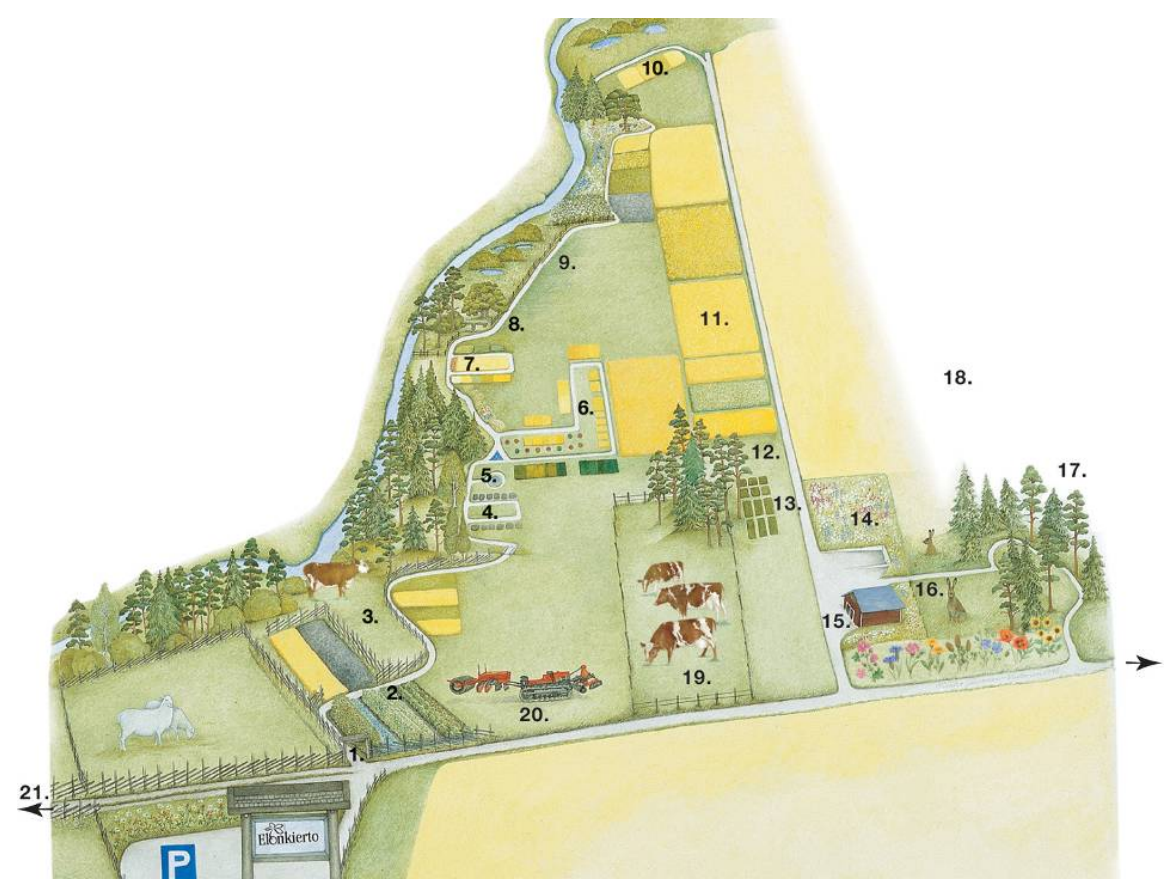

Kuva 2. Maatalouden esittelypuisto Elonkierto. 
Esittelypuisto on kymmenvuotisen olemassaolonsa aikana saavuttanut vakaan kävijämäärän. Kävijöitä on vuosittain n. 10 000, joista osa on paikkakunnalla asuvia ulkoilijoita ja osaa kauempaa tulijoita. Puistossa käy myös paljon ryhmiä.

Elonkierrossa järjestetään myös erilaisia tapahtumia, kuten keskiviikkoisin opastettuja teemakierroksia, joissa maatalousalan "julkkikset” kertovat kesäisen kävelykierron ohessa omasta suhteestaan maaseutuun ja maatalouteen. Mukana on ollut mm. ekofilosofi, kalastaja Pentti Linkola ja yrttiviljelyn johtava asiantuntija Bertalan Galambosi. Kesän 2007 aikana kuultiin kyyttöjen suojelija Miina Äkkijyrkkää. Tarjolla on myös erityisesti lapsille suunnattua toimintaa. Paikalliset koulut hyödyntävät Elonkiertoa ja siihen liittyvää MTT:n asiantuntijuutta monipuolisesti opetuksessaan.

Puisto nimettiin vuoden 2006 merkittävimmäksi mielenterveysteoksi Hämeessä. Perusteina mainittiin mm. perheiden yhteisen tekemisen ja vapaa-ajan vieton tukeminen ja omien maaseutujuurien esiin tuominen myönteisessä valossa.

\section{Maatilaleirikoulut}

Maatilaleirikoulutoimintaa on kehitetty MTT:Ilä EcoLearn -hankkeen puitteissa, joka toteutettiin EU:n LIFE-ohjelman tukemana vuosina 2002-2005. Maalle oppimaan leirikouluja varten kehitettiin yhteistyössä maatalous- ja opetusalan ammattilaisten kanssa opetuskokonaisuuksia viidestä eri teemasta: 1) maaseutumaisema- ja monimuotoisuus, 2) maaseutukulttuuri ennen ja nyt, 3) maaseudun ja kaupungin vuorovaikutus, 4) kestävät kulutusvalinnat ja ekologinen jalanjälki sekä 5) terveellinen ja laadukas ruoka Opetuskokonaisuudet on suunnattu perusopetukseen, ja ne koostuvat koulussa tehtävistä ennakko- ja jälkitehtävistä sekä toiminnallisesta osuudesta maatilalla (Smeds 2005).

Hankkeen aikana järjestettiin 12 pilottileirikoulua, joiden puitteissa testattiin sekä opetuskokonaisuuksien että yrittäjäverkoston toimivuutta pilottileirikoulussa ja MTT:n maatalouden esittelypuistossa Elonkierossa. Leirikouluja järjestettiin Hauholla, Somerolla, Jokioisilla, Alastarossa, Rantasalmella, Ypäjällä ja Kokemäeltä. Mukana oli sekä kaupunki- että maaseutukouluja ja myös erityisluokkia. Lisäksi muodostettiin verkosto yrittäjistä, jotka jo tarjoavat tai ovat kiinnostuneita tarjoamaan kouluille ympäristökasvatuspalveluja ja haluavat kehittää toimintaansa Maalle oppimaan -mallin edellyttämällä tavalla. Verkostoon ilmoittautui hankkeen aikana 50 maatilayrittäjää. Mukana on sekä maatilamatkailutiloja että kotieläintiloja.

Maaseutulähtöisen ympäristökasvatuksen laadun takeeksi on laadittu selkeät kriteerit sisältävä auditointijärjestelmä. Kriteerit täyttäville yrityksille myönnetään Maalle oppimaan -merkki, jonka pohjana on ISO 9001/2000 laatujärjestelmään perustuva Maakuntien parhaat -merkki. Maalle oppimaan -merkistä opettaja ja vanhemmat tunnistavat turvallisen, ympäristöystävällisen ja testattuja leirikoulumalleja toteuttavan leirikoulun. Kriteerit ja merkki on kehitetty osallistavan suunnittelun menetelmällä yhteistyössä eri alojen asiantuntijoiden kanssa. Maalle oppimaan -merkin myöntää Agropolis Oy. Leirikouluille kehitettiin myös leirikoulutoiminnan liiketoimintamalli (Miemois 2005), ja hankkeen aikana järjestettiin koulutusta yrittäjille, opettajille ja maaseutuneuvojille. Maalle oppimaan! - Maaseutulähtöisen ympäristökasvatuksen käsikirja perustuu hankkeessa testattuihin opetuskokonaisuuksiin ja leirikouluihin (Häkkinen 2005). Käsikirja sisältää maaseutulähtöisen ympäristökasvatuksen teoriataustaa sekä käytännön ohjeita ja toimintamallit, jotka ovat linjassa perusopetuksen opetussuunnitelman tavoitteiden kanssa.

\section{Koulu-lähimaatilayhteistyö}

EcoLearnin myönteisten kokemusten rohkaisemana maaseutulähtöistä ympäristökasvatusta jatkettiin 2006-2007 Maalle oppimaan -hankkeessa, jossa painotettiin aiempaa enemmän koulun ja paikallisyhteisön välistä vuorovaikutusta ja yhteisöllisyyttä. Toiminnassa pyritään pitkäkestoiseen yhteistyösuhteeseen, ja se edellyttää tilavierailujen säännöllistä toistuvuutta

Opettaja ja maatilayrittäjä suunnittelevat yhdessä toiminnan muodot ottaen huomioon sekä koulun ja oppilasryhmän tarpeet että maatilayrittäjän mahdollisuudet. Opetuksen 
sisältö rakentuu kunkin tilan edellytyksille, mutta pedagoginen vastuu kuuluu selkeästi opettajalle. Maatila ottaa oppilaat vastaan ja antaa tilaisuuden tutustua yrittäjän arkeen.

Paikallisuus ei ole pelkästään pitkän tähtäimen kestävyyskysymys, se on myös mitä suurimmassa määrin käytännöllinen kysymys. Kun välimatka on lyhyt, yhteinen suunnittelu ja vuoropuhelu voidaan toteuttaa kasvokkain ja toiminta joustaa tarvittaessa molempiin suuntiin lyhyelläkin varoitusajalla. Henkilökohtaisten yhteyksien kautta voidaan saada apua muilta paikallisyhteisön toimijoilta, ja kun yhteistyötila sijaitsee lähellä, myös koulujen matkakulut pysyvät kohtuullisina. Paikallisuuden periaate on vahvistanut sekä opettajien että maatilayrittäjien sitoutumista yhteistyöhön. Samalla toiminta on parantanut vuorovaikutusta koulun ja paikallisyhteisön välillä ja lisännyt lasten tietämystä omasta kotiseudustaan, mikä on tarpeen identiteetin rakentumisen kannalta.

Hanke toteutettiin Maa- ja elintarviketalouden tutkimuskeskuksen (MTT) johdolla yhteistyössä WWF:n eli Maailman luonnonsäätiön ja Tarton yliopiston kanssa vuosina 2006-2007. Kiinteää yhteistyötä tehtiin myös Hämeen luontokeskuksen, Vihdin 4Hyhdistyksen sekä virolaisen Karulan kansallispuiston kanssa. Rahoittajina olivat INTERREG IIIA ohjelma, Etelä-Suomen ja Länsi-Suomen lääninhallitukset, Viron sisäasiainministeriö. Kohdekuntina Suomessa olivat Vihti Uudeltamaalta sekä Jokioinen, Tammela ja Forssa Hämeestä. Pilottivaiheessa hankkeessa on ollut mukana 8 maatilaa, MTT:n Elonkiertopuisto, Korteniemen perinnetila Liesjärvellä ja Hämeen luontokeskus sekä 13 oppilasryhmää 4-6 luokkalaisia opettajansa kanssa. Virossa hanketoiminta keskittyi Etelä-Viroon Karulan luonnonpuiston alueelle Vörumaalle, jossa luonnonpuiston alueella sijaitsevat perinteistä maataloustuotantoa harjoittavat tilat toteuttivat alueensa kouluille vastaavanlaisia vierailuohjelmia.

Kokemukset on koottu maatilayrittäjille ja opettajille yhteisesti suunnattuun oppaaseen, joka ohjaa ja opastaa koululaisvierailujen suunnittelussa ja toteutuksessa. (Risku-Norja \& Aaltonen 2007).

\section{Kokemuksia}

Sekä opettajien että yrittäjien kokemukset koulumaatilayhteistyöstä ovat pääosin myönteisiä. Molemminpuolinen avoin ja rehellinen palaute mahdollisimman pian on tärkeätä. Siten vältytään tilanteilta, joissa jokin asia jää vaivaamaan jompaakumpaa osapuolta.

Tärkeimmäksi asiaksi yrittäjiltä saadussa palautteessa on noussut halu antaa oikeaa tietoa ja oikoa ennakkoluuloja ja muuttaa asenteita myönteiseen suuntaan. Samalla haluttiin saada lapset kiinnostumaan maataloustöistä ja näin tiloille mahdollisesti jatkajia. Tilallisten mielestä oli myös tärkeää, että lapset oppivat, mistä ruoka tulee. Siten kotimaisen ruoantuotannon arvostuskin paranee. Lähes kaikki mukana olleet tilat olivat valmiita suosittelemaan toimintaa muillekin maatiloille. Yhteistyö koulujen kanssa nähtiin mahdollisuutena erityisesti pienille tiloille.

Maatilayhteistyöhön osallistuneet opettajat ovat yhtä mieltä siitä, että kaikki mikä on jotain muuta kuin koulun seinien sisällä istumista, on tervetullutta vaihtelua oppilaille ja opettajille. Maatilayhteistyö on mielekästä ja onnistuu yleensä hyvin, koska lapset yleensä viihtyvät luonnossa ja eläinten parissa. Lisäksi toiminta palkitsee nekin oppilaat, jotka eivät aina kaikessa muussa onnistu. Opettajat näkivät maatilan todenoloisena oppimisympäristönä, missä opetettiin käytännöllisiä asioita.

Tiettyjen asiasisältöjen oppimisen lisäksi on muitakin näkökohtia, jotka puoltavat toimintaa. Konkreettinen tekeminen maatilalla yhdessä muiden oppilaiden kanssa vahvistaa lasten yhteistyötaitoja. He oppivat työskentelemään yhdessä, auttamaan toisiaan ja ottamaan vastuuta tekemästään työstä. Lapset oppivat myös käyttäytymistä uusissa tilanteissa ja uusien ihmisten kanssa. Varsinkin pienikokoisista eläimistä huolehtiminen ja niiden hoito on tunteisiin vetoavaa. Se opettaa myötäelämisen kykyä ja herättää tarpeen helliä ja vaalia. Elämyksellisyyden kautta syntyy asenteita, jolloin tietoakin on helpompi omaksua. Yhteistyö on tehokasta asennekasvatusta maaseudun puolesta, ja lasten kautta tietoa ja ymmärrystä kulkeutuu myös vanhemmille. 
Ongelmiakin oli, mutta monet niistä nähtiin alkuvaiheen hankaluuksina. Kun toiminta vakiintuu, vakiintuvat myös käytännöt. Suurimpana ongelmana opettajat pitivät ajan puutetta, sillä toiminnan suunnittelu ja käytännön järjestelyt vaativat runsaasti aikaa. Kustannukset eivät kuitenkaan ole olleet koulun kannalta kynnyskysymys. Sen sijaan saattaa olla ongelmallista löytää innostuneita opettajia järjestämään maatilayhteistyötä. Ilman työyhteisön tukea ja sitoutumista yhden opettajan on vaikea viedä asiaa eteenpäin. Koulun johdon ja kunnan koulutoimen tuki ja kannustus ovat keskeisiä. Maalle oppimaan -leirikouluyrittäjät veloittavat normaalikäytännön mukaisesti, pilottivaiheessa koululähimaatilayhteistyössä puolestaan yrittäjien korvaus maksettiin hankerahoituksesta, $2 €$ oppilasta ja tuntia kohden.

\section{Johtopäätökset}

On sanottu, että tehokkain tapa edistää kestävää kehitystä on kasvattaa uusi sukupolvi, joka nykyistä paremmin omaksuu kestävän kehityksen tavoitteet osaksi ajatusmaailmaansa ja elämäntapaansa. Koulu-maatilayhteistyö edistää tällaista kasvatusta. Toiminnan vaikutukset tähtäävät tulevaisuuteen, aikaan, jolloin nykylapset ja -nuoret ovat kuluttajia ja päättäjiä. Tavoitteena on lisätä heidän tietämystään ympäristöstä, luonnon ja kulttuurin vuorovaikutuksesta ja maaseutualueiden merkityksestä. Samalla vahvistuu koulun ja yhteiskunnan keskinäinen vuorovaikutus, ja oppilaat ankkuroituvat omaan kotiseutuunsa. Kestävyyden ekologinen ulottuvuus on vahvasti mukana toiminnassa, jossa ihmisen vaikutus luontoon ja ympäristön kantokyky ovat koko ajan näkyvissä ja arvioitavana.

Maatilayrittäjälle yhteistyö on ennen kaikkea oivallinen tilaisuus suhdetoimintaan. Kun viljelijä avaa maatilansa yleisölle, hän samalla kuulee ulkopuolisten näkemyksiä työstään ja pystyy niiden pohjalta paremmin tuomaan oman näkökulmansa keskusteluun. Lasten ja nuorten myönteiset kokemukset ja vahvat elämykset maatilalla kulkevat lasten mukana koteihin ja muokkaavat asenteita siellä. Parhaimmillaan oppilaista on myös todellista apua: he tarttuvat talikkoon, huolehtivat eläimistä, tekevät klapeja, istuttavat metsää tai rakentavat aitaa. Yhteistyö vaatii maatilayrittäjältä kuitenkin jonkin verran ylimääräistä vaivannäköä ja ennen kaikkea aikaa, ja siksi hän ansaitsee siitä kohtuullisen korvauksen. Koulumaatilayhteistyö onkin yksi monista palvelumaatalouden muodista (Nergård \& Verstad 2004, Hassink \& Dijk 2006). Tulevaisuuden kannalta tärkeä kysymys on pysyvän rahoituslähteen löytyminen yrittäjille.

Lapsille ja nuorille maatila tarjoaa uusia tietoja ja taitoja. Omakohtainen kosketus maatilan töihin lisää heidän kykyään ymmärtää ja arvostaa erilaisia ihmisiä ja erilaista työtä. Maatilalla opitaan nimenomaan omin käsin tekemällä, jolloin myös käytännöllisesti suuntautuneet oppijat saavat näyttää osaamistaan ja kokevat onnistumisia.

Maatila-kouluyhteistyö sopii erittäin hyvin perusopetukseen. paitsi aihekokonaisuuksien opettamiseen myös oppiainekohtaiseen opetukseen. Ympäristö- ja luonnontiedon sekä biologian ja maantiedon lisäksi toiminnasta on tukea melkeinpä aineessa kuin aineessa, muun muassa liikunnassa (tilalle kulkeminen), kuvaamataidossa (käden taidot ja kokemusten kertaaminen taiteen keinoin), äidinkielessä (oppimispäiväkirjat), historiassa (vanhat työkoneet ym. tilan esineet) ja matematiikassa (eläinten ruokintaa koskevat laskutoimitukset tms.). Ala-asteen opettajat, jotka itse hoitavat suurimman osan ryhmänsä opetuksesta, voivat helposti sovittaa tilavierailut eri oppiaineiden tavoitteisiin.

Yhteistyö maatilojen kanssa tuo oppimiseen lisää kokemuksellisuutta, elämyksellisyyttä ja toiminnallisuutta, tekemällä oppiminen ja mahdollisuus opitun soveltamiseen ovat keskeisiä. Kun oppiminen on sidoksissa myönteisiin kokemuksiin ja konkreettiseen tilanteeseen, opittavien asioiden merkitys voidaan osoittaa helposti, ja oppilaat pystyvät soveltamaan oppimiaan asioita käytännössä ja hankalatkin käsitteet avautuvat. Näin omaksuttu tieto vaikuttaa myös asenteisiin ja arvoihin ja konkretisoituu lopulta toimintana omassa elämässä (Wals et al. 1999, Winne 2005). Tekemällä oppiminen antaa lapselle mahdollisuuden kehittyä kokonaisvaltaisesti, omakohtaisten 
kokemuksien kautta. Myös sosiaalinen vuorovaikutus ja osallisuus ovat vahvasti mukana. Oppilaskeskeiset työtavat vahvistavat yhteistyötaitoja ryhmätilanteissa. Yhteiset tavoitteet ja yhdessä työskentely lisäävät keskinäistä solidaarisuutta ja kykyä ottaa huomioon toiset ihmiset ja heidän tarpeensa. Osallisuus antaa oppilaille tunteen siitä, että he ovat oman ryhmänsä ja koulunsa jäseniä, että he pystyvät vaikuttamaan asioihin ja ovat vastuussa tekemisistään. Opetus on tilannesidonnaista ja kun siihen vielä liittyy elämyksellisyys ja yhdessä tekeminen, voidaan puhua kokonaisvaltaisesta oppimisesta. Maatilat tarjoavat toimintaympäristön, jossa opetussuunnitelman tavoitteita voidaan toteuttaa käytännön tekemisen ja kokemusten kautta.

Koulujen ja maatilojen yhteistoiminta on käynnistynyt ripeästi, ja kokemukset siitä ovat olleet hyvin myönteisiä. Tekemisen riemu ja innostus saavat uskomaan, että maalle kannattaa mennä oppimaan. Yleensä maatilakäyntejä ei kuitenkaan ole kirjattu opetussuunnitelmaan eikä kouluille ole osoitettu määrärahoja tähän nimenomaiseen tarkoitukseen. Näin ollen opetuksen toteutus riippuu paitsi opettajien omasta aktiivisuudesta myös siitä, miten ulkopuolisen yhteistyön käytännöt ovat kouluissa muotoutuneet ja miten aktiivista varainhankintaa oppilaat ja heidän vanhempansa ovat harrastaneet.

”Paras tapa oppia. Käytännön työ opettaa paljon enemmän kuin asioiden lukeminen kirjasta”, kommentoi eräs koululainen maatilapäivänsä hyviä puolia. Huonoja ei sitten oikein ollutkaan - paitsi aluksi se sikalan haju.

\section{Viitteet}

Cantell, H. (toim.) 2004. Ympäristökasvatuksen käsikirja. Jyväskylä: PS-kustannus.

Cantell, H. \& Koskinen, S. 2004. Ympäristökasvatuksen tavoitteita ja sisältöjä. Cantell, H. (toim.). Ympäristökasvatuksen käsikirja. Jyväskylä: PS-kustannus. s. 60-79.

Chawla, L. 1999. Life paths into effective environmental action. The Journal of Environmental Education 31, 1: 15-26.

Hassink, J. \& Dijk, M.v. (toim.) 2006. Green-Care Farming Across Europe and the United States of America. Wageningen UR Frontis Series,Vol. 13. $357 \mathrm{~s}$.

EcoLearn. http//www.agronet.fi/leirikoulut

Elonkierto. http//www.mtt.fi/elonkierto

Häkkinen, J. (toim.) 2005. Maalle oppimaan! Maaseutulähtöisen ympäristökasvatuksen käsikirja. Finfood - Suomen ruokatieto ry. www.finfood.fi. Libris, Helsinki: $60 \mathrm{~s}$.

Maalle oppimaan. http//www.agronet.fi/maalleoppimaan

Miemois, A. 2005. Recept ur markanadsförarens kokobok: Ingredienser och tillredningsanvisningar för en inbjudande lägerskola - Miljölägerskola Eco Learn. Jordbruk och livsmedelsekonomi 65, $52 \mathrm{~s}$

Nergård, T. \& Verstad, B. 2004. Farm - School cooperation. A new entrepreuneurial arena producing social capital and local identity. Paper to working group 16: Renewal of local community through endogeneoous rural development, social capital, community, social identity and new rural groups at XI World Congress of Rural Sociology. Trondheim, Norway: s. 1-15.

Niemi, J. \& Ahlstedt, J. (toim.) 2006. Finnish Agriculture and Rural Industries 2006. MTT Agrifood Research Finland, Economic Research, Publications 106a Helsinki: Edita. 96 s.

Palmer, J.A. 1998. Environmental education of the 21st century: Theory, practice, progress and promise. London: Routledge. $284 \mathrm{~s}$.

Risku-Norja, H. \& Aaltonen, V. (toim.) 2007. Maalle oppimaan. Kestävää kehiotystä koulujen ja lähimaatilojen yhteistyönä. Maa ja elintarviketalous. Jokioinen: MTT Agrifood Research Finland. $66 \mathrm{~s}$.

Risku-Norja, H. 2006. Vastuu ympäristöstä, hyvinvoinnista ja kestävästä tulevaisuudesta aihekokonaisuus kuntien opetussuunnitelmissa ja koulujen käytännöissä. Maalle oppimaan maaseutulähtöisen ympäristökasvatuksen verkosto Suomessa ja Virossa. Esiselvitys. http:Ilwww.agronet.fi/maalleoppimaan/Front\%20page/julkaisut/.

Saloranta, S. 2005. Luontokasvatuksesta kestävän elämäntavan kasvatukseen. Houtsonen, L. \& Åhlberg, M. (toim.) Kestävän kehityksen edistäminen oppilaitoksissa. Hakapaino, Helsinki: Opetushallitus. s. 45-51.

Siltala, H. \& Kaivola, T. 2003. Ruoan reitti: maaseutulähtöisen ympäristökasvatuksen kehittämishanke Elonkierto-puistossa. Lovén, L. (toim.): Ympäristökasvatus - Environmental Education. Helsinki: Metsäntutkimuslaitos. s. 153-170. 
Smeds, P. 2005. Maalle oppimaan - toimintamallit. Häkkinen, J. (toim.) Maalle oppimaan! Maaseutulähtöisen ympäristökasvatuksen käsikirja. Helsinki: Finfood. s 22-55

Wahlström, R. 1997. Ympäristöherkkyys ja sen edistäminen ympäristökasvatuksessa. Ympäristökasvatus 97, 1: 20-21.

Wals, A., Albas, H. \& Margadant-van Arcken, M. 1999. Environmental education for human development. Wals, A. (toim.). Environmental education and biodiversity. Wageningen, Netherlands: Natural Reference Centre for Nature Management. s. 15-33.

Winne, M. 2005. Education for change. Journal of Agricultural and Environmental Ethics , 18: 305-310.

Åhlberg, M. 2005. Eheyttävän ympäristökasvatuksen teoriasta kestävää kehitystä edistävän kasvatuksen teoriaan. Houtsonen, L. \& Åhlberg, M. (toim.) Kestävän kehityksen edistäminen oppilaitoksissa. Hakapaino, Helsinki: Opetushallitus. s. 158-175. 